\title{
Case Study of Children of Referrals to Health Services: An Individualizing Design?
}

\author{
Carina Alexandra Rondini, Camila Incau, Verônica Lima dos Reis-Yamauti \\ Departamento de Psicologia Experimental e do Trabalho, Faculdade de Ciências e Letras-FCL, Universidade \\ Estadual Paulista "Júlio de Mesquita Filho" - UNESP, Assis, Brazil \\ Email: carina@assis.unesp.br, veronica.reis@nepps.com.br
}

Received 5 February 2015; accepted 23 February 2015; published 26 February 2015

Copyright $\odot 2015$ by authors and Scientific Research Publishing Inc.

This work is licensed under the Creative Commons Attribution International License (CC BY).

http://creativecommons.org/licenses/by/4.0/

(c) (i) Open Access

\begin{abstract}
Nowadays education for all is recommended as an international action. However in Brazil one can observe homogeneous practices for a heterogeneous public. When the student has learning difficulties, there seems to be an attempt to normalization and pathologization by the means of referral, many times being indiscriminate, to health services. This case study aimed to analyze records of pedagogical strategies to meet the students educational needs before sending them to health services. Two records sent to a multidisciplinary team of a Regional Specialty Clinic (ARE) in a city of the state of São Paulo/Brazil, were used. The results reflect that the records of the educators do not show the pedagogical strategies used with the students and that the education system still seeks homogeneous classes, devaluating the diversity present in its context.
\end{abstract}

\section{Keywords}

Pathological, Diversity, Learning Problems, Health Services

\section{Introduction}

In modern era, childhood begins to be seen as a time of preparation and prevention for the formation of productive and healthy individuals. It begins in this period, the interventions on childhood care from prevention settings, moralizing and educational practices. Thus, the establishment of the school appears as an expression of the very modern constitution of childhood (Guarido, 2010).

The school performance in modernity is related to the child's ability to remain quiet and seated. In order to meet these requirements the child needs to control and adjust their behavior (Seno, 2010). The school often requires students to pay attention to everything that is presented to them, even when, in most cases, the content does not make sense. Also that do not show irritation and restlessness even when the situation at school is un- 
bearable (Meira, 2012). In addition, it is expected that children become independent, learn quickly and various contents and depend a little on adults who surround them (Rojas, 2010).

Students who do not meet the school requirements are usually labelled as sick, lazy or unmotivated, and referred to the healthcare services (Nakamura, Lima, Tada, \& Junqueira, 2008). By labelling the student, the school does not recognize, does not reflect and does not act on their teaching practices, and ends up blaming only the child (Souza, Ignatius, \& Carvalho, 2009). In this way the school ceases its function and produces problems that will be treated as demands for health in different social spaces as public and private health services, mental health and psychology clinics (Meira, 2012).

The difficulty on learning or behaving is currently designed by the school as an individual problem, as a personal failure (Beltrame \& Boarini, 2013; Sanchez \& Amarante, 2014). This belief makes these children to be subjected to a large number of examinations and tests seeking the biological cause of the difficulty on learning or behaving (Sanches \& Amarante, 2014). The relationship between neurological problems, learning problems and behavior becomes, then, is increasingly common in school referrals to public and private services in the health field (Meira, 2012).

Referrals made by the school disregard existing conditions and situations in the school environment (Nakamura et al., 2008). Still in modernity, the relationships developed between teachers and students generate dependency links that are often pathologizing to produce alienation and frustration in both parties (Meira, 2012). An example of this gap in student-teacher ratio is the idealization of a perfect student. Currently there is a disharmony between the real and the ideal student. The teacher who idealizes students is generating a difficulty of dealing with behavior that contrasts with the idealized posture, and the traditional education system collaborates with the illustration of the existence of a perfect student. Therefore, the student who does not meet the expectations tends to be worked to fit the school environment (Landskron \& Sperb, 2008).

Teachers, who have greater contact with students, are the ones that identify symptoms and refer to health services; the main complaints made by these professionals are behavior and learning difficulties in the classroom. (Souza \& Mosmann, 2013). About it, Guarido (2010) states that the knowledge of psychology, influenced by modern medicine, enabled the teachers to become extensions of an expert look in everyday practice since they come to observe the children's behavior changes and guide their family in the search for appropriate treatments to the problems presented by the students in the school.

According to Sanches and Amarante (2014) there was an increase in referral of children to mental health services with social demands. Research done in 2013 supported this claim. The researchers Beltrame and Boarini (2013) reported that in a Children and Youth Psychosocial Care Center (CAPSi) in the state of Paraná, there was an increase of children of referrals to health services. About $60.0 \%$ of cases were referred by the school, the main complaints learning problems and behavior in schools. Souza and Mosmann (2013) report that about $15.5 \%$ of the demands of a CAPSi in São Paulo refer to academic problems.

The main behaviors that generate referrals are inattention and restlessness. These behaviors produce discomfort in various contexts, but it is at school where most calls their control (Landskron \& Sperb, 2008). According to Nunes, Tank, Costa, Furlan and Schnell (2013) referral of children to psychology clinics done by schools is the most frequent demand in psychological clinics in Brazil, the main reason for this routing Deficit Disorder and Attention hyperactivity disorder (ADHD). Thus, the school acts more as a space for diagnosis than a pedagogical space (Sanches \& Amarante, 2014).

\section{Subjectivity of School Records: An Issue to Be Thought}

According to Landskron and Sperb (2008) the records made by teachers show that the referral of children for mental health service with learning difficulties occurs without first these children be evaluated pedagogically. Being so, the researchers describe how it is questionable how diagnoses are made, since they are based on subjective interpretations of parents and teachers on children's behavior. Still, an analysis of records made by Sanches and Amarante (2014) reports that the school decreases the workload of children with inappropriate behavior within the school as a way of pressuring parents to solve the problem. With this attitude, the school environment was more punitive and remiss than welcoming.

The school believes it has exhausted all the possibilities of working with the difficulties of the student when the sends for ealth, but the institution does not thinks on their practices, blaming only the child (Beltrame \& Boarini, 2013). Methods, resources and homogenizing pedagogical practices are not questioned, ignoring the 
diversity present in school. Each student is unique, his/her personality, his/her way of expressing satisfaction or dissatisfaction with the system must be respected. Blames on him/her for the failure of the education system is hurting the Universal Declaration of Human Rights of 1948 (UNESCO, 1998a) which states that "everyone has the right to education"; the Convention on the Rights of the Child (Brazil, 1990) that in Art.28, item "d" professes that it is the state's duty to make information and educational guidance available and accessible to all children; the World Declaration on Education for All (UNESCO, 1998b) which underlines the importance of expanding educational approach, expressing what it takes "universal access to education and promoting equity; to focus on learning; broadening the means and the basic education sphere of action; provide a suitable learning environment; strengthen alliances." (p. 4). Note that the approach focuses on the delivery of education to students and the restructuring of the education system recognizing "that, in general terms, the education that is provided today has serious shortcomings, which is needed to make it more relevant and improve its quality, and that it should be universally available” (p. 3). In addition to being a signatory of these international actions, Brazil also has the Statute of Children and Adolescents-ACE (Brazil, 2009), which in Article 54, Paragraph §2 states that the "irregular supply of teaching matters for the Competent Authority" (p. 33).

In this context, Copetti (2012) brings to discussion the question "What is 'try everything'?" (p. 17), where it says "traditional medical examinations may, at most, diagnose medical problems that are very probably related to learning problems, such as a brain tumor, for example, [...] however, do not diagnose deficits underlying the learning problems, which ultimately are truly causing the school problem." So when the doctor says there is nothing wrong with the examination of the child, family and/or school questions-why not? If he does not learn! if he/she does not stop! if he/she does not pay attention! and, failing that health/disease, then considers the child "lazy", "disinterested", or any other pure and simply belonging to the child (Copetti, 2012).

On the other hand, when the diagnosis occurs, the school ratifies it, accepting and reproducing the medical discourse (Brzozowski \& Caponi, 2009). The medical diagnosis is seen, at school, as unquestionable and its guidelines are received as order by teachers (Landskron \& Sperb, 2008), resulting in a justification for the fact that the student does not learn.

Of particular concern is the issue related to the diagnosis of ADHD and High Abilities/Giftedness. Antshel (2008) explains that students with an IQ above 140 can be misdiagnosed as having ADHD since they have similar characteristics, such as focused attention only in areas/topics of interest and vulnerability to boredom that do exhibit behaviors considered to be inappropriate in the environment school. In these cases, a misdiagnosis could result in medicalization of a highly talented student, dulling their potential and exempting educators to invest in diversified educational practices.

Considering these notes, one might think then natural of acceptance of an analysis which revealed a problem with the student, since this is more acceptable, since "return" the case to the school without a possible solution, other than a "disease/disorder", would show a weakness in the school system, which is not "welcome". Thus it is not a surprising increase in the prescription of drugs for the treatment of students (Guarido, 2010; Landskron \& Sperb, 2008; Meira, 2012).

Reinforcing this view, Sanches and Amarante (2014) say that parents and teachers demonstrate a lack of discussion on the conflicts that occur in schools through the records. Further, according to Nakamura et al. (2008), the teachers often report records their efforts to assist in learning or to control the student in the classroom. And to what extent will these efforts go?

In search of answers we undertook this study ${ }^{1}$ to analyze in two records, referred to a multidisciplinary team of a Regional Specialty Clinic (ARE), in a city in the state of São Paulo with just over 400,000 inhabitants, teaching strategies records to meet the educational needs of students before forwarding them to health services.

\section{Casuistry}

The case study was accomplished in two medical records forwarded to the ARE, one by a Pedagogical Coordinator, attesting to the evaluation of the teacher, and the other by the teacher. It is boys' records at the time of the study, the in third and fourth grades of elementary school, respectively. To maintain confidentiality on the identity of the students, they will be identified by $\mathrm{X}$ and $\mathrm{Y}$, respectively. In addition, to preserve school's identity, educational coordinator and teacher chose not to photocopy the records, however, faithful and fully transcribe

${ }^{1}$ This study was approved by the Ethics Committee of the Institute of Biosciences, Arts and Exact Sciences-UNESP/SJRP on September 12,2011 under the advice of $n^{\circ} 076 / 11$. 
their content:

" $X$ is 8 years old and is enrolled in this school unit since May 2011 attending the 3rd year of elementary school. The student is participating, has quiet a behavior, is shy and gets a lot of sense when a colleague makes comments about him or his work. As for school performance, especially this school year, has shown interest and a desire to overcome his difficulties. In [relation to] writing and reading development he has less than expected. In dictation he demonstrates to be in the alphabetical stage, but to prepare a text or a sentence, he has great exchange of letters, confuses not only the neighboring phonemes $(f / v, p / b)$ placing letters at random leaving writing sometimes incomprehensible. In reading comprehension, when reading alone, he cannot have clarity of the proposed activities. In oral he expresses opinions only when asked. In mathematical reasoning there were great advances, the student can perform the operations and problem situations when the statement is read by the teacher. The teacher reports that after stopping the medication the student had more difficulties both in mathematical reasoning as in reading and writing. He presented tiredness, sluggishness and lack of concentration. There is great concern in part of the regular teacher and ESA's service teacher [Educational Service Specialist], because $X$ sometimes demonstrates a great advance while other times he seems to regress and does not match with which is required." (Our italics)

" $Y$ is 9 years. He presents writing with round hand letters (all tied up), but he can make reading his writing. He does not perform the activities proposed in the classroom, but he has a good oral understanding. Because he does not carry out the activities, he stays observing the colleagues, he expresses verbal aggression, especially in relation to colleagues' parents and grandparents. He stands up all the time from his place to sharpen pencil, to get glue, scissors, for any or no reason, he leaves the place throwing down materials from colleagues, he kicks, slaps, etc. He does not focus on activities, he has no patience to listen to explanations, he makes jokes, he questions real facts and he tries to twist them. When asked, he denies his attitudes, he screams and cries. He has a habit of biting his tongue, he chews all that he meets: pencil, plastic rubbers, clothes, etc. In an attempt to improve, he was changed from the classroom where he remained for a month and a half. Unfortunately there was no progress and he returned to the original room. There are no changes in his behavior, he is less and less performing the proposed activities. The mother is always present and follows the incomplete activities, asking him to accomplish them at home.” (Our italics)

\section{Results and Discussion}

For the presentation of results and discussion, we created categories of analysis as presented in italics description of the records, which we present below.

\subsection{The School behind the Records-Description of Students: An Individualizing View}

The two charts bring different complaints of his students to the area of health. The first describes the student shares the activities, he has a quiet behavior, is shy and gets a lot of sense when a colleague makes comments about him or his work. There is a behavioral complaint in this case, since the student does not present behaviors considered socially inadequate, but the school forwards the student to the health area seeking answers for absence on learning.

The second chart depicts that the student does not focus on the activities, he has no patience to listen to explanations, he makes jokes, he questions real facts and he tries to twist them. Here the behavior displayed by the student bothers educators who tend to refer its origin to his family, however, the mother is always present, in an attempt to find answers for the absence of learning and for behavior considered inappropriate, the solution was to direct him to health services, focusing the problems on the student himself.

According to Masini (2013), educational professionals knowledge is omitted when seeking to classify learning disability looking for something of organic order. Similarly Guarido and Voltolini (2009) in a psychoanalytic and grounded in Foucault debate, argue that there is a disclaimer from teacher to consider that absence of learning is due to physical problems, leaving "few gaps for that education to be seen as a link between adults and children that can result in some kind of transformation” (p. 255).

To change this logic inculcated in the educational setting, one needs to rebel against the process of teaching and learning, considering the diversity of students present at school, valuing the diversity in this social context. However, "rather than rebel against teaching and its structure, the East prefers, however, to remedy the consequences of the anomalies generated by inadequate teaching of our time. Remedy the effects means, in this case, 
to instruct medicine to answer where teaching failed” (Mannoni, 1988: p. 49).

The homogeneous model shows to be inappropriate at school for everyone, recommended by the World Declaration on Education for All (UNESCO, 1998b). We have overcome the vision of the elitist school, although without all that the developing countries require, as it is the case of Brazil. The school for all requires a broad view of the school context and of the singularities in which it is engendered. A school is different from another, a student is different from the other, which makes us question-How to use the same teaching strategies for different populations? As a different student in his/her needs and potentialities can learn if the education system still favors homogeneity?

One needs to value the diversity of our children which, according to Machado (2013) start the multiplicity of livings through questions, trials and curiosities, but this is rebuked in the current logic of ruling operation of schools. Multiplicity of experiences becomes to be unwanted and becomes controlled, so such full development would not be harmed? Although, we have not opted for an approach to the discussion in this study. We believe that a Vygostki's historical-cultural perspective, development occurs through learning and this in turn happens in the social context to which a person lives; thus we can argue that in an environment where the child is prevented from experience through social relations, from different forms of expression, his/her development would be harmed or at least minimized to what it is expected from her-not excel standardization.

\subsection{In the Classroom: The Pathologizing Relationships Established at School}

According to the school, $\mathrm{X}$ presented tiredness, sluggishness, lack of concentration and, $\mathrm{Y}$, raises all the time from the place for sharpening pencils, to take glue, scissors, for any or no reason, he leaves the place, throws down materials from colleagues, kicks, slaps, etc.

Here we ask: what kind of student is school looking for? We observed the reinforcement of studies by Sanches and Amarante (2014), Beltrame and Boarini (2013) and Souza and Mosmann, since referrals to health services have difficulties related to schooling, which we can infer to be associated with an unthinking social demand and on pedagogical practices of a traditional school, but without an ideal student seeks alternatives to its regulation (Landskron \& Sperb, 2008).

To Masini (2013), the school needs to understand and accept that children daily receive a variety of information in real time by means of communication; this makes them to produce divergent behavior from the one awaited by the school. It appears, then, according to Rojas (2010) that the requirement level of the stimulus generated by the media can produce a hyperactive, inattentive as well as and impulsive child, once the ideals emerging regarding immediation and urgency on the part of contemporary society, do not favor the development of ideas as delaying, waiting and thinking of a future order. Thus, the school demands some children's behavior and society encourages and produces other forms of behavior.

\subsection{Prescription Drugs: A Solution to Unexpected Behavior in the Classroom}

It is observed in the first chart that the teacher reports that after stopping medication, the student had more difficulties both on mathematical reasoning as on reading and writing. Ferrazza and Rocha (2011) state that, from the moment when psychological distress is labelled as a pathology, a biological disease, treatment happens only by prescription of psychotropic drugs. To Crochik and Crochik (2010) this is because health professionals try to solve school problems outside the institution, failing to observe the influence of the school environment on children. Still, Eidt and Tuleski (2007) say that often drugs are used as a tool to create normal standards. The authors believe that medication prescription is an attempt to build someone without conflicts, anguish and limitations. Therefore, according to Machado (2013), medicalization process in school decreases singularity and the process of differentiation on children at school, as the attempt to homogenize students shows.

As for the second chart, it does not describe if the student makes use of medication, but studies in recent years (Brant \& Carvalho, 2012; Crochik \& Crochik, 2010; Guarido, 2010; Eidt \& Tuleski, 2007; Ferrazza \& Rock, 2010; Landskron \& Sperb, 2008; Machado, 2013; Meira, 2012) on behaviors of agitation and impulsivity in schools make us infer that possibly this child will be medicated. This happens, according to Crochik and Crochik (2010), because the problems witnessed in the school are understood as physical or psychological and, therefore, deserve to be treated with medication and psychotherapy.

Decotelli, Bohrer and Bicalho (2013) lecture on medicalization during childhood and biopower spheres discussed by Foucault. The authors say that Brazil is the second largest consumer of Ritalin, a drug indicated for 
the treatment of ADHD, which was renamed as the "obedience drug" as it provides opportunities for educators to solve the difficulties presented in school, that is for the behaviors considered to be inappropriate to the school environment. Guarido and Voltolini (2009), expressing concern and rejection to this model that aims to pathologizing human experiences in order to control what comes out of the norm, so sadness turns into deppression, anguish and anxiety disorder, problems with writing in dyslexia, agitated behavior in ADHD, and (unfortunately) among other examples.

What draws our attention is the "possible" solution that the school had taken to resolve the student Y's difficulties: In an attempt to improve, we changed Y's classroom, where he remained for a month and a half. Unfortunately there was no progress and he returned to the original room. We observed that the reports of medical records do not describe the teaching strategies used with students, to find those that best suited for them, which contradicts Nakamura et al. (2008) when they say that teachers report in the medical records their efforts to promote student learning. Here we cannot say that such attempts did not exist, however, we can argue that the records do not bring this important information which could also assist health professionals in the assessment of students, discarding diseases. What worries us is that the focus is on the student, as responsible for his/her difficulties and the lack of information in the medical records relieves the school from its responsibility on educating students what is against the World Declaration of Human Rights (UNESCO, 1998a), the Convention on the Rights of child (Brazil, 1990), the World Declaration on Education for All (UNESCO, 1998b) and the ECA (Brazil, 2009).

It seems is that the school, when meeting a student who "does not fit" to its "model" sees in health something that can solve its problems, as argued Landskron and Sperb (2008), Nakamura et al. (2008) and Meira (2012).

We need to think on the growth of the pharmaceutical industry in an increasingly growing market, and Guarido and Voltolini (2009) denounce the marketing done by them in a capitalistic society which aims at quick wins, leaving aside the human experiences as something unwanted, pathologizing and applying drugs emotions, subjectivity, diversity and measuring the student failure of a losing educational system, where "drugs entry occurs right there in the place before occupied by the teacher, or the teacher is not the drugs anymore (...)" (p. 257).

Overburdened teachers? Highly-numbered classes? Too-fulfilled with contents to be taught? External examinations requirements (Prova Brazil, SARESP, etc.) $)^{2}$ ? Low wages? Deficient training? Lack of incentives-internal and external to the school environment? Whatever be the reasons on which are based educators, the fact is that increasingly we have less and less time to listen to our students, know them beyond the academic contents in a traditional school, still concerned with subjects. No doubt this helps us to understand our students less and simply classify them "fit for our school" or "not fit for our school". The educational system demands thoughts in its structure, as well as schools for diverse teaching practices. Valuing diversity, seeking teaching strategies that cover diversity—-these are school needs for everyone.

\section{Conclusions}

We found in this case study that were referred to health services two students with different background complaints, the first on learning and the second, on behavior. Thus, what seems is not to exist a "profile" specific complaint that is "appropriate" to this referral. It seems that if the student does not have an appropriate profile to the school he must be referring to health services as an option of "adequacy" of "adjustment".

We have thought all the text long that the school is covered by diversity, based on laws that indicate an enriched service that takes into account time and students learning style, however this did not unfortunately mean the teaching action.

We are immersed in paradoxes-society and school change in completely different periods and the student needs, as one who has a key in his/her cognitive and behavioral system, change it according to the environment he/she is in, sometimes schooling, sometimes social, looking for all the time to adapt to these systems, as a penalty to be segregated. In Brazil, the health system is completely devoided from the educational system, and this generates conflicts and differences, because each one has some observation lens on that student.

One possible way to such paradoxes would be collaborative teamwork (Capellini, Zanatta, \& Pereira, 2008; Capellini, 2010; Zanata \& Capellini, 2013)—the collective discussion of such cases within the school, even in

\footnotetext{
${ }^{2}$ Prova Brasil: national survey used to calculate the Idesp (Development Index of the São Paulo State Education). SARESP: test applied annually by the Department of Education of São Paulo (ESS/SP) to assess the basic education of the state system.
} 
the early, lasses of elementary school; we must think on homogenizing practices and seek for educational alternatives for different students present in the school context.

Therefore, it is necessary to develop a culture that values diversity; the record in medical records is relevant, it is necessary to work out information about the teaching strategies used with the student, providing the health team with data not only focused on the student, but in the context in which he is inserted, in this case, the school community. One must consider the student's records as relevant-that needs to be constantly updated, approaching the school system of the health system, but not only in the form of immediate referral, but also as a form of consultation, observation, and consulting. Moreover, the health area should be aware that the school is surrounded by a social, political and cultural context, being the organic aspects only one of the dimensions involved.

\section{References}

Antshel, K. M. (2008). Attention-Deficit Hyperactivity Disorder in the Context of a High Intellectual Quotient/Giftedness. Developmental Disabilities Research Reviews, 14, 293-299. http://dx.doi.org/10.1002/ddrr.34

Beltrame, M. M., \& Boarini, M. L. (2013). Mental Health and Childhood: Reflexions on the School Demand of a CAPSi. Psicologia: Ciência e Profissão, Brasília, 33, 336-349. www.scielo.br/scielo.php?pid=S1414-98932013000200007\&script=sci_arttext

Brant, L. C., \& Carvalho, T. R. (2012). Metilfenidato: Medicamento gadget da contemporaneidade. Interface - Comunicação, Saúde, Educ., Botucatu, 16, 623-636. www.scielo.br/scielo.php?pid=S1414-32832012000300004\&script=sci_arttext http://dx.doi.org/10.1590/S1414-32832012000300004

Brasil (1990). Convenção sobre os Direitos da Criança. Decreto No 99.710, De 21 De Novembro De 1990. http://www.planalto.gov.br/ccivil_03/decreto/1990-1994/D99710.htm

Brasil (2009). Estatuto da Criança e do Adolescente. Lei No 8.069, De 13 De Julho De 1990. http://www.planalto.gov.br/ccivil_03/leis/18069.htm

Brzozowski, F. S., \& Caponi, S. (2009). Transtorno de déficit de atenção com hiperatividade: classificação e classificados. Physis Revista de Saúde coletiva, Rio de Janeiro, 19 , 1165-87. www.madres.org/documentos/doc20110113141936.pdf http://dx.doi.org/10.1590/S0103-73312009000400014

Capellini, V. L. M. F, Zanata, E. M., \& Pereira, V. A. (2008). Práticas educativas: Ensino colaborativo. Bauru: UNESP/FC/ MEC.

Capellini, V. L. M. F. (2010). O ensino colaborativo favorecendo políticas e práticas educativas de inclusão escolar na educação infantil. In S. L. Victor, \& J. F. Chicon (Orgs.), A Educação Inclusiva de Crianças, Adolescentes, Jovens e Adultos: Avanços e desafios (pp. 83-108). Vitória: EDUFES.

Copetti, J. (2012). Dificuldades de aprendizado: Manual para pais e professores. Curitiba: Juruá.

Crochik, J., \& Crochik, N. (2010). A desatenção atenta e a hiperatividade sem ação. In Conselho Regional de Psicologia de São Paulo; Grupo Interinstitucional Queixa Escolar (Org.), Medicalização de crianças e adolescentes: Conflitos silenciados pela redução de questões sociais a doenças de indivíduos. São Paulo: Casa do Psicólogo.

Decotelli, K. M., Bohrer, L. C. T, \& Bicalho, P. P. G. (2013). A Droga da Obediência: Medicalização, Infância e BiopoderNotas Sobre Clínica e Política. Psicologia: Ciência e profissão, 33, 446-459.

Eidt, N. M. \& Tuleski, S. C. (2007). Discutindo a medicalização brutal em uma sociedade hiperativa. In M. E. M. Meira, \& M. G. D. Facci (Orgs.), Psicologia Histórico-Cultural: Contribuições para o encontro entre a subjetividade e a educação (pp. 221-248). São Paulo: Casa do Psicólogo.

Ferrazza, D. A., \& Rocha, L. C. D. (2011). A psicopatologização da infância no contemporâneo: Um estudo sobre a expansão do diagnóstico de "transtorno de déficit de atenção e hiperatividade”. Revista Internacional Interdisciplinar INTERthesis, 8, 237-251.

Guarido, R. (2010). A biologização da vida e algumas implicações do discurso médico sobre a educação. In: Conselho Regional de Psicologia de São Paulo; Grupo Interinstitucional Queixa Escolar (Orgs.), Medicalização de crianças e adolescentes: Conflitos silenciados pela redução de questões sócias a doenças de indivíduos (pp. 27-39). São Paulo: Casa do Psicólogo.

Guarido, R., \& Voltolini, R. (2009). Que não tem remédio, remediado está? Educação em Revista, 25, 239-263. http://dx.doi.org/10.1590/S0102-46982009000100014

Landskron, L. M. F., \& Sperb, T. M. (2008). Narrativas de professoras sobre o TDAH: Um estudo de caso coletivo. Revista semestral da Associação Brasileira de Psicologia escolar e educacional, 12, 153-167. http://www.scielo.br/pdf/pee/v12n1/v12n1a11.pdf

Machado, A. M. (2013). Uma nova criança exige uma nova escola: A criação do novo na luta micropolítica. In C. A. L. 
Collares, M. A. A. Moysés, \& M. C. F. Ribeiro (Orgs.), Novas capturas, antigos diagnósticos na era dos transtornos (pp. 191-202). Campinas: Mercado de Letras.

Mannoni, M. (1988). Educação impossível. Rio de Janeiro: Francisco Alves.

Masini, L. (2013). Uma nova criança exige uma nova escola. In C. A. L. Collares, M. A. A. Moysés, \& M.C. F. Ribeiro (Orgs.), Novas capturas, antigos diagnósticos na era dos transtornos (pp. 181-190). Campinas: Mercado de Letras.

Meira, M. E. M. (2012). Para uma crítica da medicalização na educação. Revista semestral da Associação Brasileira de Psicologia Escolar e Educacional, 16, 135-142. www.scielo.br/scielo.php?script=sci_arttext\&pid=S1413-85572012000100014

Nakamura, M. S., de Lima,V. A. A., Tada, I. N. C., \& Junqueira, M. H. R. (2008). Desvendando a queixa escolar: Um estudo no Serviço de Psicologia da Universidade Federal de Rondônia. Revista Psicologia Escolar e Educacional, Maringá, 12, 423-429. http://www.scielo.br/pdf/pee/v12n2/v12n2a13.pdf

Nunes, M. R. M., Tank, J. A., Costa, S. M. D., Furlan, F., \& Schnell, L. C. (2013). O professor frente às dificuldades de aprendizagem: Ensino público e ensino privado, realidades distintas? Revista de Psicologia, Fortaleza, 4, 63-74. http://www.revistapsicologia.ufc.br/index.php?option=com_content\&id=146\%3Ao-professor-frente-as-dificuldades-de-ap rendizagem-ensino-publico-e-ensino-privado-realidades-distintas\&Itemid=54\&lang=pt

Rojas, M. C. (2010) Perspectiva familiar y social. In: B. Janín (Ed.), Niños desatentos e hiperativos ADD/ADHD: Reflexiones critricas acerca del transtorno por Déficit de Atención con o sin hiperactividad. Buenos Aires: Noveduc.

Sanches, V. N. L., \& Amarante, P. D. C. (2014). Estudo sobre o processo de medicalização de crianças no campo da saúde mental. Revista do centro Brasileiro de estudos de saúde, 38, 506-514. www.scielo.br/pdf/sdeb/v38n102/0103-1104-sdeb-38-102-0506.pdf

Seno, M. P. (2010). Transtorno do déficit de atenção e hiperatividade (TDAH): O que os educadores sabem? Revista psicopedagogia, 27, 334-43. http://pepsic.bvsalud.org/pdf/psicoped/v27n84/v27n84a03.pdf

Souza, F. R. D., \& Mosmann. C. P. (2013). Crianças e adolescentes encaminhados para psicoterapia pela escola: Percepções de Genitores e Professores. Revista da SPAGESP, 14, 39-54.

http://pepsic.bvsalud.org/scielo.php?pid=S1677-29702013000200004\&script=sci_arttext

Souza, V. A. D., Inácio, C. B., \& Carvalho, L. S. (2009). Desafios do cotidiano escolar: Repensando a prática de ensino e a dificuldade de aprendizagem. In Anais III EDIPE. Encontro Estadual de Didática e Prática de Ensino: Professores: entre os desafios do cotidiano escolar e a realização profissional, 2009, Anápolis, Goiânia. Anápolis, GO: Viera. http://www.ceped.ueg.br/anais/IIIedipe/pdfs/3 posteres/gt09 didatica praticas ensino estagio/post gt09 desafios do co tidiano_escolar.pdf

UNESCO_United Nations Educational, Scientific and Cultural Organization (1998a). Declaração Universal dos Direitos Humanos. http://unesdoc.unesco.org/images/0013/001394/139423por.pdf

UNESCO_United Nations Educational, Scientific and Cultural Organization (1998b). Declaração Mundial sobre Educação para Todos. http://unesdoc.unesco.org/images/0008/000862/086291por.pdf

Zanata, E. M., \& Capellini, V. L. M. F. (2013). A construção de uma escola inclusiva por meio da colaboração. In E. C. Konkiewitz (Org.), Aprendizagem, Comportamento e Emoções na Infância e Adolescência (pp. 281-291). Dourados, MS: UFGD. 
Scientific Research Publishing (SCIRP) is one of the largest Open Access journal publishers. It is currently publishing more than 200 open access, online, peer-reviewed journals covering a wide range of academic disciplines. SCIRP serves the worldwide academic communities and contributes to the progress and application of science with its publication.

Other selected journals from SCIRP are listed as below. Submit your manuscript to us via either submit@scirp.org or Online Submission Portal.
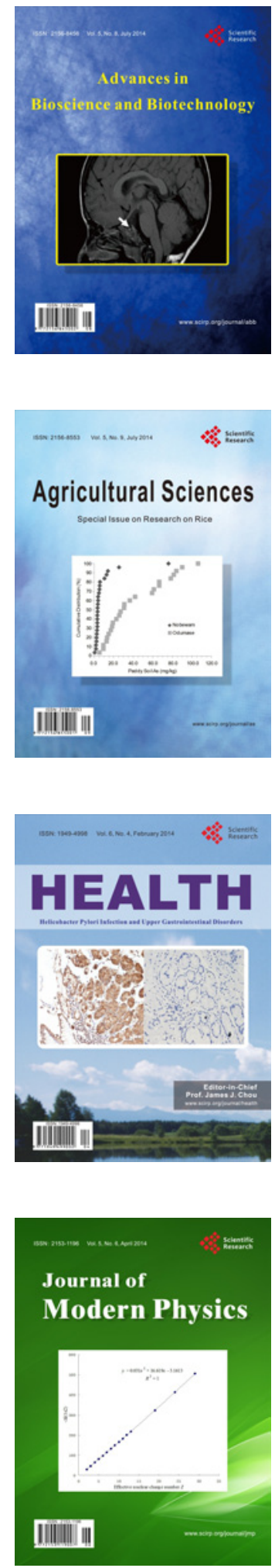
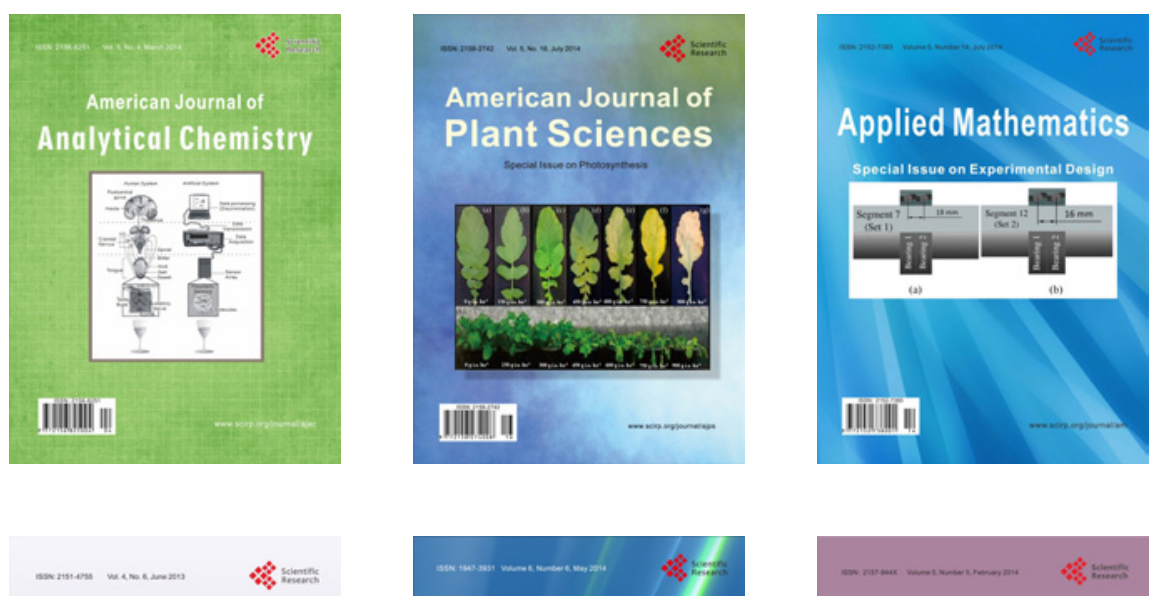

Creative Education
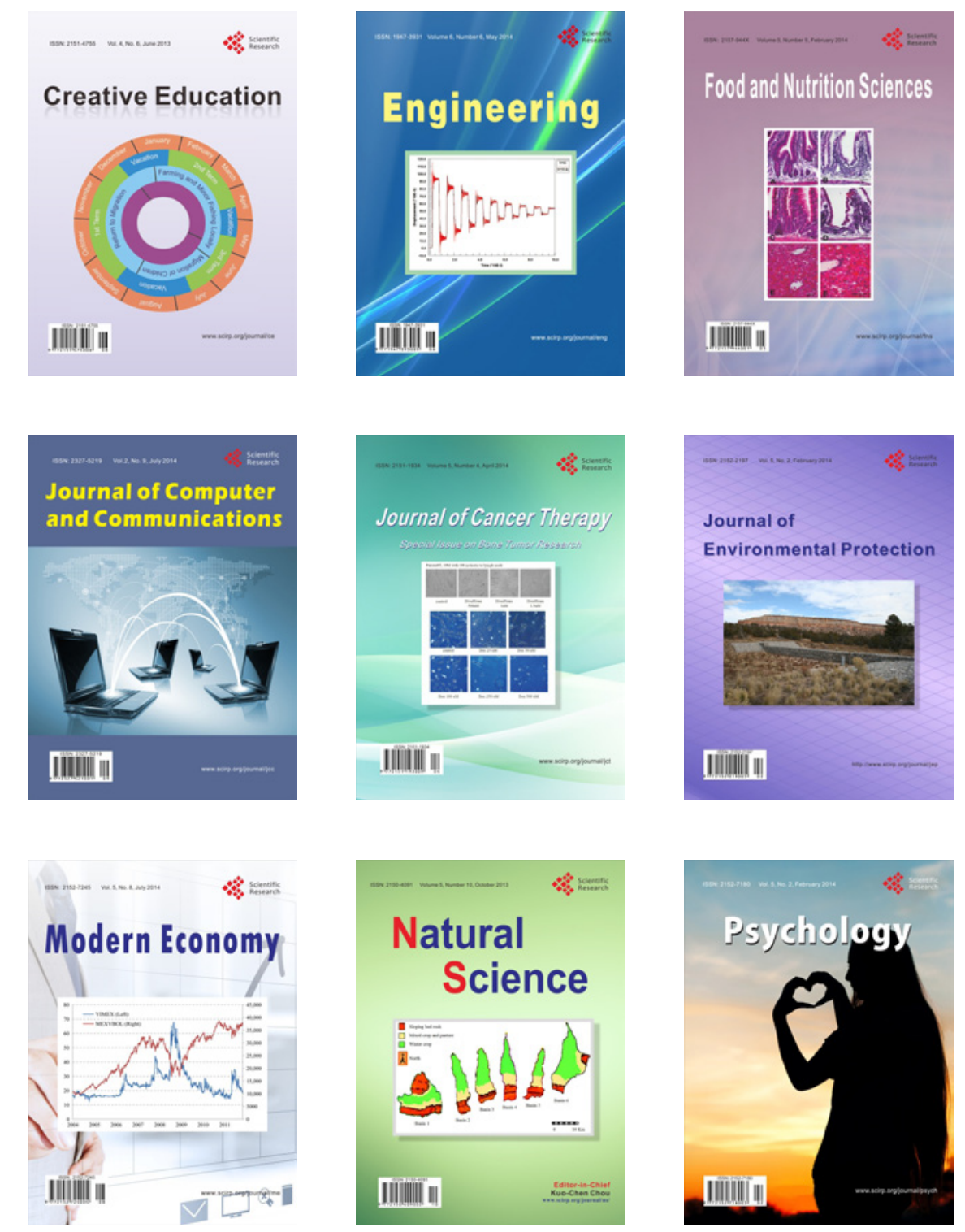